\title{
Segmentasi Citra Kartu Pias Tipe SO-40U (1400-40S) Pada Perhitungan Lama Penyinaran Matahari
}

\author{
Asih Pujiastuti \\ Program Studi Teknik Informatika \\ Sekolah Tinggi Teknologi Adisutjipto Yogyakarta \\ asihpuii@stta.ac.id
}

\begin{abstract}
The measurement of the duration of solar irradiation at the climatology station can be done using campbell stokes and pias cards. The aim of this research is to assist the climatology station operator to determine the burn object on the SO-40U (1400-40S) type of pias cards, making it easier to calculate the duration of solar irradiation. This app is designed and built to successfully segmentation the burn on the card automatically. In this research, the data was collected at a climatology station located in Barongan, Sumberagung Jetis, Bantul. Based on the test conducted segmentation generated in this study is good and produce RMSE number of object result of segmentation equal to 2,6485 to sum object in original image. The difference in object calculation results from a segmentation error caused by a small burning object of the pias card and or a thin but translucent object, so that the object is partially lost or forms an object's separation area.
\end{abstract}

Keywords:segmentation, image,solar irradiation, RMSE

\begin{abstract}
Abstrak
Pengukuran lama penyinaran matahari di stasiun klimatologi dapat dilakukan dengan alat Campbell stokes dan kartu pias. Penelitian ini bertujuan untuk membantu operator stasiun klimatologi untuk menentukan objek bekas bakar pada kartu pias tipe SO-40U (1400-40S), sehingga mempermudah perhitungan lama penyinaran matahari. Aplikasi perangkat lunak yang dirancang dan dibangun dapat melakukan segmentasi bekas bakar pada kartu secara otomatis. Aplikasi ini dirancang dan dibangun agar dapat melakukan segmentasi bekas bakar kartu pias secara otomatis. Pada penelitian ini pengambilan data dilakukan di stasiun klimatologi yang terletak di Barongan, Sumberagung Jetis, Bantul. Berdasarkan pengujian yang dilakukan segmentasi yang dihasilkan pada penelitian ini baik dengan menghasilkan RMSE jumlah objek hasil segmentasi sebesar 2.6485terhadap jumlah objek pada citra asli.Selisih hasil perhitungan objek disebabkan oleh kesalahan segmentasi yang disebabkan oleh objek bekas bakar kartu pias yang kecil dan atau objek tembus namun tipis, sehingga objek sebagian hilang atau membentuk area pemisah objek.
\end{abstract}

Kata kunci: segmentasi, citra, penyinaran matahari, RMSE

\section{Pendahuluan}

Perhitungan hasil pengukuran lama penyinaran matahari oleh operator stasiun klimatologi dengan menggunakan alat campbell stokes dan kartu memerlukan ketelitian dan konsitensi penilaian terhadap objek pembakaran yang terekam pada kertas pias. Penentuan objek bekas bakar yang valid menentukan keakuratan hasil perhitungan. Penentuan objek menjadi penting dikarenakan adanya objek bekas bakar yang tidak sempurna yang tidak termasuk perhitungan, ketidaksempurnaan objek tersebut disebabkan oleh kekuatan matahari yang tidak melampaui $120 \mathrm{~W} / \mathrm{m}^{2}$ (Hamdi, 2004) ataupun kerusakan kartu. 
Pada penelitian ini merancang dan membangun sebuah system yang bertujuan membantu operator menentukan objek bekas bakar kartu pias sehingga menghasilkan output yang tepat dan konsisten. Alat bantu yang digunakan adalah scanner untuk memindai kartu pias pada proses akuisisi citra. Metode yang diimplementasikan adalah segmentasi untuk menghilangkan objek diluar objek target atau disebut dengan noise. Output yang dihasilkan system berupa objek hasil segmentasi dan jumlah objek. Data uji yang dipakai adalah kertas pias tipe SO-40U (1400-40S).

\section{Tinjauan Pustaka}

Berdasarkan referensi penelitian yang sudah pernah dilakukan sebelumnya dan dijelaskan pada bab ini, akuisisi kartu pias dipindai dengan menggunakan scanner. Menurut Horseman, dkk., (2012), pada penelitiannya dilakukan manipulasi proses akuisisi citra dengan memberikan background warna merah. Hal yang sama dilakukan oleh SanchezRomero, dkk,.(2014) , pada penelitiannya juga memanipulasi warna background pada saat akuisisi citra, yang berbeda adalah warna yang digunakan adalah hijau. Tujuan manipulasi warna background kedua penelitian adalah mempermudah untuk mendapatkan objek penyinaran matahari yang terekam pada kartu pias. Sedangkan pada penelitian Fan dan Zang (2013) tidak melakukan manipulasi warna background pada saat akuisisi citra kartu pias.

Horseman, dkk., (2012) dalam penelitiannya mengembangkan metode semi-otomatis yang sistematis untuk mengektrasi citra kartu pias dari Campbell Stokes tanpa mengatur posisi kartu pada saat pemindaian. Metode threshold digunakan untuk mendapatkan area objek yang berwarna merah. Ekstrasi citra kartu pias dengan menggunakan metode prototipe kemudian diuji dibandingkan dengan catatan dari pirheliometer. Hasil perbandingan menunjukkan karakteristik mirip antara data Campbell Stokes dengan data pirheliometer.

Sanchez-Romero, dkk., (2014) dalam penelitian yang dilakukan hampir sama seperti Horseman,dkk.,(2013) dengan metode threshold. Metode threshold digunakan untuk mendapatkan area objek penyinaran dengan warna manipulasi hijau saat akuisisi. Perbedaan penelitian keduanya adalah fokus penelitian Sanchez-Romero, dkk., (2014) yaitu mencari korelasi hasil data dari dua tipe model Campbell stoke sunshine recorder, serta mencari hubungan data yang diperoleh dengan data direct solar irradiance. Penelitian dilakukan dengan menggunakan gambar RGB dan Image processing Toolbox dari MatLab.

Fan dan Zang (2013) pada penelitian dilakukan dengan tujuan untuk mendapatkan seluruh objek penyinaran yang terekam pada kartu pias dengan menggunakan metode Multivariablethresholding dan deteksi tepi canny. Hasil implementasi kedua metode yang digunakan mampu untuk mengekstrak objek penyinaran kuat dan lemah, kemudian memperbandingkan konsistensi metode dengan citra asli. Berbeda Fan dan Zang (2013), Pujiastuti dan Harjoko (2016) melakukan penelitian perhitungan lama penyinaran matahari dengan metode otsu threshold. Penelitian yang dilakukan lebih memfokuskan proses threshold dengan metode otsu untuk segmentasi. Hasil penelitiannya menjelaskan bahwa metode otsu threshold dapat membantu binerisasi citra sebagai dasar proses segmentasi kartu pias.

\section{Landasan Teori}

\subsection{Lama Penyinaran Matahari}

Lama penyinaran matahari adalah lamanya matahari bersinar cerah pada permukaan bumi, yang dihitung mulai dari matahari terbit hingga terbenam, dan ditulis dalam satuan jam sampai nilai persepuluhan atau sering ditulis dalam satuan persen terhadap panjang hari maksimum (Ariffin, dkk., 2010). 


\subsubsection{Campbell Stokes}

Campbell Stokes merupakan salah satu alat perekam penyinaran matahari. Campbell stokes ditemukan oleh John Francis Campbell pada tahun 1853 kemudian dimodifikasi oleh Sir George Gabriel Stokes pada tahun 1879. Alat ini terdiri dari bola pejal terbuat dari bahan gelas dengan diameter 4 inchi yang dipasangkan pada kedudukannya sehingga sinar matahari dapat difokuskan pada kartu pias dengan tajam (Strangeways, 2003). Campbell stokes dapat dilihat pada gambar 3.1.

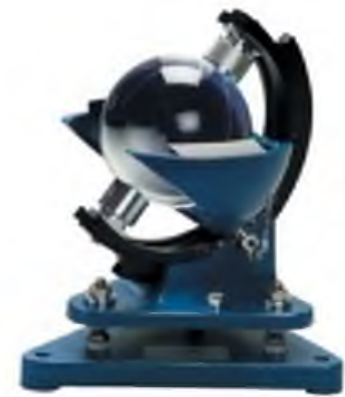

Gambar 3. 1. Campbell Stokes

\subsubsection{Kartu Pias Tipe SO-40U (1400-40S)}

Kartu Pias Tipe SO-40U (1400-40S) merupakan alat perekam lama penyinaran matahari yang digunakan pada periode tanggal 15 April - 31 Agustus, dapat dilihat pada gambar 3.2. Kartu pias merupakan alat untuk merekam lamanya penyinaran matahari yang dipasangkan pada Campbell stokes. Kartu pias ini terbuat dari karton, berwarna biru gelap, dapat menyerap dan mudah terpenyinaran oleh radiasi matahari. Skala pada kartu pias dimulai dari pukul 06.00 sampai dengan pukul 18.00 .

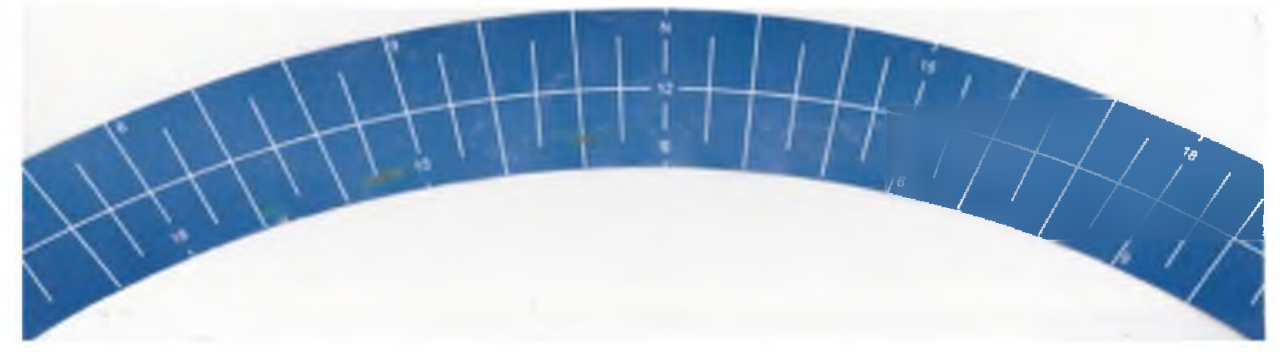

Gambar 3. 2. Kartu pias tipe SO-40U (1400-40S)

\subsection{Preprocessing}

Tujuan utama dari preprocessing citra adalah untuk meningkatkan kualitas citra dimana citra yang dihasilkan dapat memberikan informasi yang lebih jelas bagi manusia sehingga memudahkan dalam melakukan interpretasi atas suatu citra (Kuivalainen, 2005).

\subsubsection{Grey Scale}

Tujuan proses grey-scale dalam preprocessing citra adalah untuk mengubah citra berwarna umumnya citra dengan format RGB menjadi citra keabuan. Adapun untuk mendapat citra grey-scale dari citra berwarna maka digunakan persamaan (3.1) :

$$
f_{0}(x, y)=\frac{f_{i}^{R}(x, y)+f_{i}^{G}(x, y)+f_{i}^{B}(x, y)}{3}
$$




\subsubsection{Median Filter}

Filtering pada citra digunakan untuk mengurangi adanya noise pada citra yang bisa saja disebabkan oleh adanya debu pada citra, kamera yang tidak fokus ataupun pencahayaan yang tidak merata. Median filter sendiri merupakan filter yang hasilnya berdasarkan pada pengurutan nilai piksel yang dilingkupi oleh filter yang ditentukan oleh nilai median dari setiap piksel.

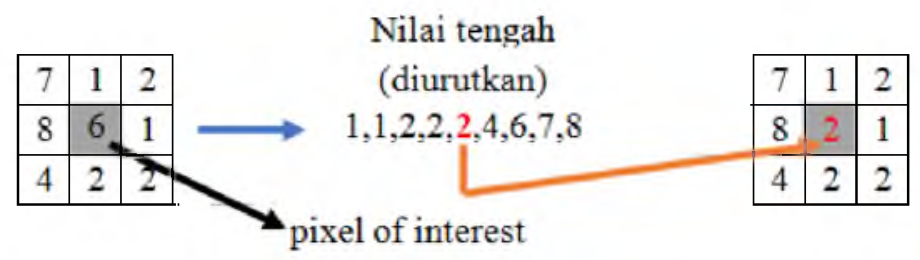

Gambar 3. 3. Median filter

\subsubsection{Theshold}

Thresholding atau ambang batas merupakan salah satu pendekatan segmentasi berbasis daerah (region-based approach). Pada persamaan (3.2), nilai intensitas yang lebih kecil dari nilai ambang merupakan daerah pertama dan nilai intensitas yang sama atau lebih dari nilai ambang merupakan daerah kedua yang mana salah satu daerah akan menjadi daerah latar belakang (Wu, dkk., 2008)

$$
g= \begin{cases}0, & \text { jika } f(x, y)<T \\ 1, & \text { jika } f(x, y) \geq T\end{cases}
$$

dimana $g(x, y)$ adalah citra biner dari citra keabuan/grey $f(x, y)$ dan $T$ menyatakan nilai ambang.

\subsubsection{Complement}

Proses komplemen dilakukan dengan cara scan pixeldari kiri ke kanan, dan atas ke bawah. Jika nilai pixel 0 , maka nilai pixel diubah menjadi 1 . Begitu juga sebaliknya jika nilai pixel 1 , maka diubah menjadi 0 .

\subsection{Segmentasi}

Segmentasi citra merupakan proses memisahkan piksel-piksel yang merupakan bagian dari objek pada citra dengan piksel-piksel yang bukan merupakan bagian dari objek (Gonzales dan Woods, 2008). Dalam penelitian ini, proses segmentasi dilakukan dengan metode connected component labelling, opening dan noise removing.

\subsubsection{Connected Component Labeling}

Connected component labeling merupakan metode untuk memberikan label pada citra biner (background dan object) terhadap setiap piksel yang merupakan object, dimana pikselpiksel yang saling berhubungan (connected) diberi label yang sama. Umumnya label yang diberikan penomoran berdasarkan urutan region (connected component) yang terlebih dahulu ditemukan pada proses scanningcitra . 


\subsubsection{Noise Value Removing}

Region objek yang dihilangkan adalah region objek dengan jumlah piksel yang ditentukan dan region objek dengan berada pada tepian citra.

1. Mencari region objek hasil dari proses component connected labeled, jika luas area atau jumlah pixel $\square$ noise removing value maka region objek dihapus,

2. Mencari region objek hasil dari proses component connected labeled, jika terdapat koordinat titik pada region objek yang merupakan tepi dari citra $(x=0$ atau $y=0)$ maka region objek dihapus.

\section{Metodologi Penelitian}

\subsection{Diagram Alir Data}

Entitas luar sistem ini adalah operator stasiun klimatologi. Aktifitas yang dilakukan operator dalam sistem ini adalah mengumpulkan data dan merekam data kartu pias menggunakan scanner. Citra hasil capture dari scanner disimpan pada computer. Pada proses segmentasi, operator memasukkan citra yang ada ke dalam sistem. Hasil dari proses segmentasi adalah citra objek bekas bakar dan jumlahnya. Gambaran perancangan sistem seperti pada diagram konteks Gambar 3.4.

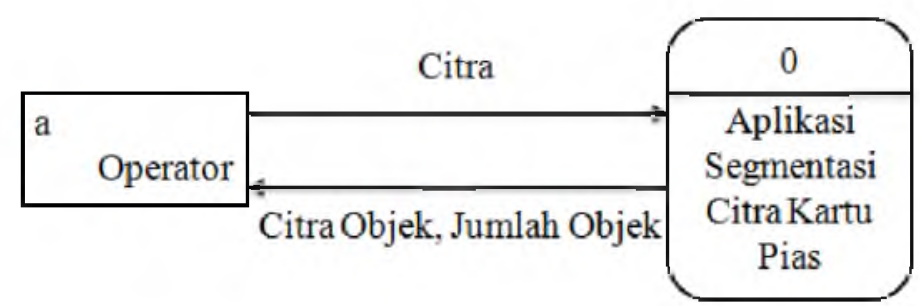

Gambar 3. 4. Diagram kontek system

\subsection{Flowchart}

Flowchart sistem merupakan gambaran prosedur yang menjadi acuan dalam berjalannya sebuah sistem. flowchart aplikasi segmentasi citra kartu pias dapat dilihat pada Gambar 4.1.

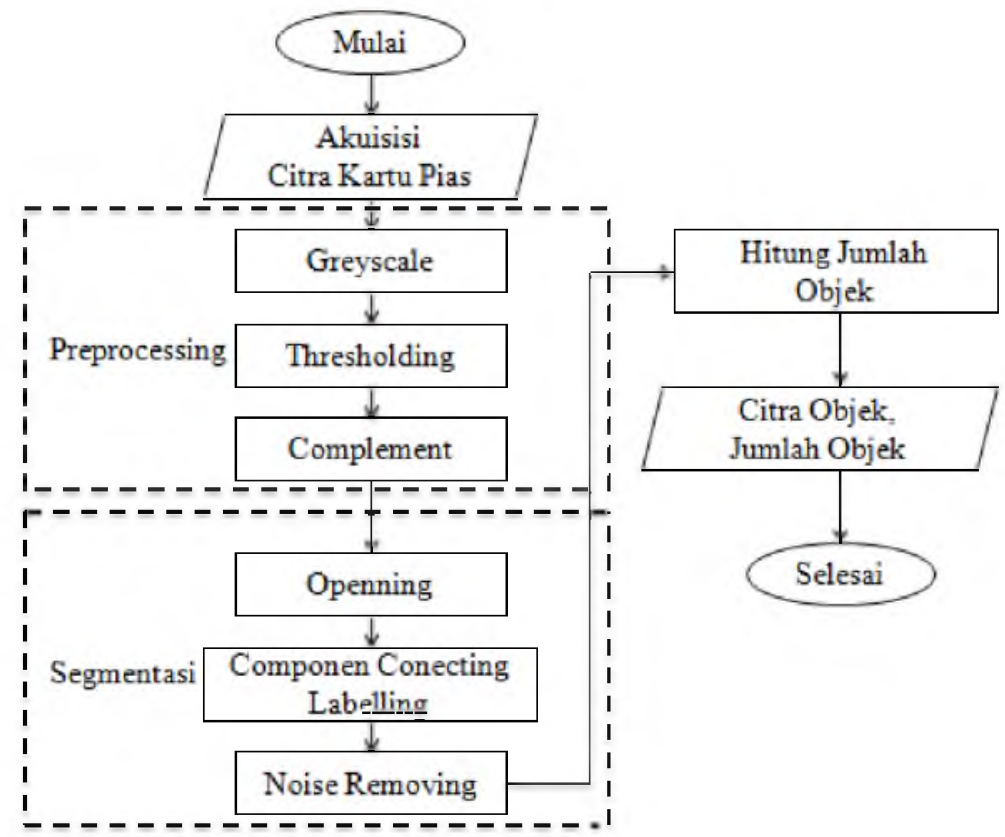

Gambar 4. 1. Flowchat system 


\subsection{Perancangan Interface}

Rancangan interface system dirancang sederhana dalam satu tampilan yang mengakomodir keseluruhan proses dan tahapan pada aplikasi. Tujuan perancangan ini agar operator dapat dengan mudah menjalankan aplikasi sekaligus melihat proses dan hasilnya. Perancangan interface system dapat dilihat pada gambar 4.2.

\begin{tabular}{|c|c|c|c|c|}
\hline \multicolumn{4}{|c|}{ Akuisisi Citra } & \multirow{4}{*}{ Citra Asli } \\
\hline Perfile & Per & older & Batal & \\
\hline \multicolumn{2}{|c|}{ Preprosesing } & \multicolumn{2}{|c|}{ Segmentasi } & \\
\hline \multirow{2}{*}{\multicolumn{2}{|c|}{$\begin{array}{l}\text { DGreyscale } \\
\text { aThreshold } \\
\text { aComplement }\end{array}$}} & \multirow{2}{*}{\multicolumn{2}{|c|}{$\begin{array}{l}\text { DOpening } \\
\text { aNoise Remove }\end{array}$}} & \\
\hline & & & & Citra Preprosesing \\
\hline \multicolumn{2}{|c|}{ Proses } & \multicolumn{2}{|c|}{ Tutup Aplikasi } & \\
\hline \multicolumn{2}{|c|}{ Source data } & \multicolumn{2}{|c|}{ |Jumlah objek } & Citra Segmentasi \\
\hline
\end{tabular}

Gambar 4. 2. Perancangan Interface

\section{Pengujiandan Analisa Hasil}

\subsection{Uji Fungsi}

Pengujian fungsi pada penelitian ini dilakukan sesuai tahapan algoritma system yang dibangun. Tujuan dari pengujian fungsi system yang dilakukan denganmemastikan seluruh metode yang diimplementasikan pada system berjalan sesuai dengan perancangan system.

a) Uji Fungsi Akuisisi Citra

Pada uji fungsi akuisisi citra dapat dilakukan dengan dua cara, yaitu menampilkan gambar perfile terpilih ataupun perfolder terpilih. Hasil dari uji fungsi akuisisi citra dapat dilihat pada gambar 5.1

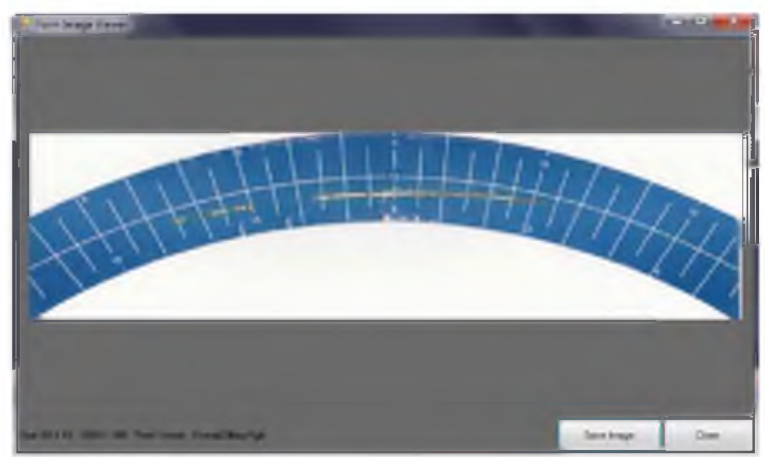

Gambar 5. 1. Implementasi Akuisisi Citra

b) Uji Fungsi Greyscale

Uji fungsi grayscale dilakukan dengan memilih parameter grayscale pada aplikasi. 
Hasil dari pengujian yang dilakukan, aplikasi yang dibangun dapat menghasilkan citra keabuan seperti gambar 5.2

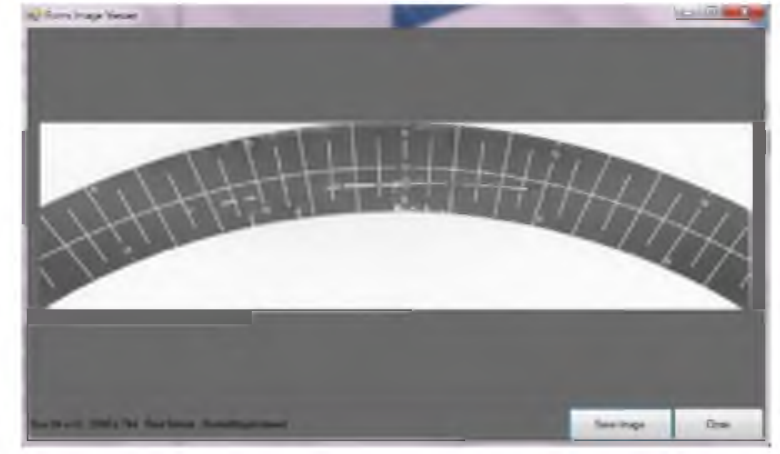

Gambar 5. 2. Implementasi Output Greyscale

c) Uji FungsiThreshold

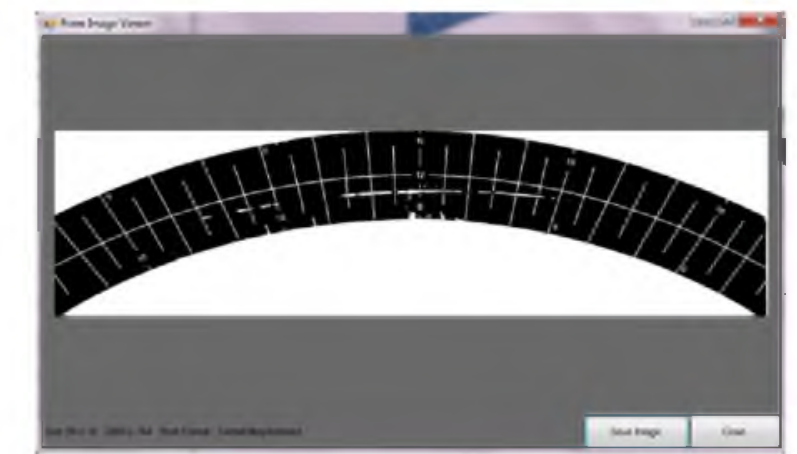

Gambar 5. 3. Implementasi Output Tresholding

Tujuan dari threshold adalah mengubah citra keabuan menjadi citra biner. Uji fungsi threshold yang dilakukan dapat menghasilkan citra biner sesuai dengan perancangan yang sudah dilakukan pada bab sebelumnya. Hasil uji fungsi threshold dapat dilihat pada gambar 5.3.

d) Uji Fungsi Complement

Fungsi complement pada aplikasi ini bertujuan untuk membalik citra biner yang telah dihasilkan, sehingga objek bekas bakar yang menjadi target terlihat jelas. Hasil uji fungsi complement menunjukan bahwa citra yang dihasilkan merupakan kebalikan dari citra biner sebelumnya. Pada awalnya objek pada citra biner berwarna putih, setelah dilakukan fungsi complement objek bekas bakar menjadi hitam. Dapat dikatakan bahwa, fungsi complement mengubah setiap pixel bernilai 1 ke 0 dan sebaliknya. Hasil uji fungsi ini dapat dilihat pada gambar 5.4.

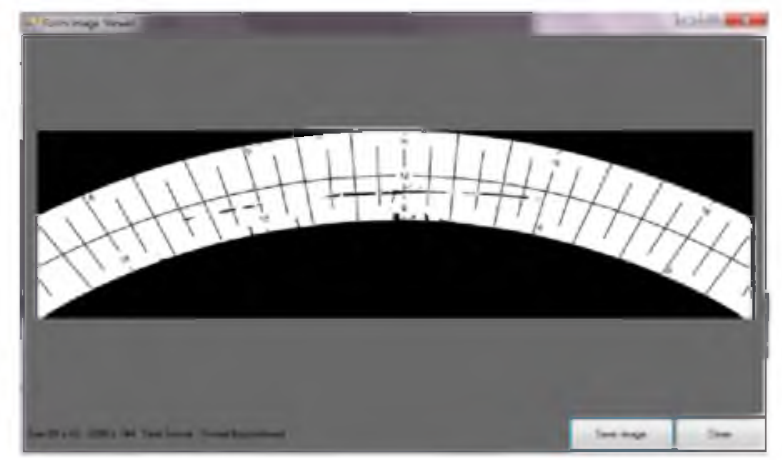

Gambar 5. 4. Implementasi Output Complement 
e) Uji Fungsi Opening

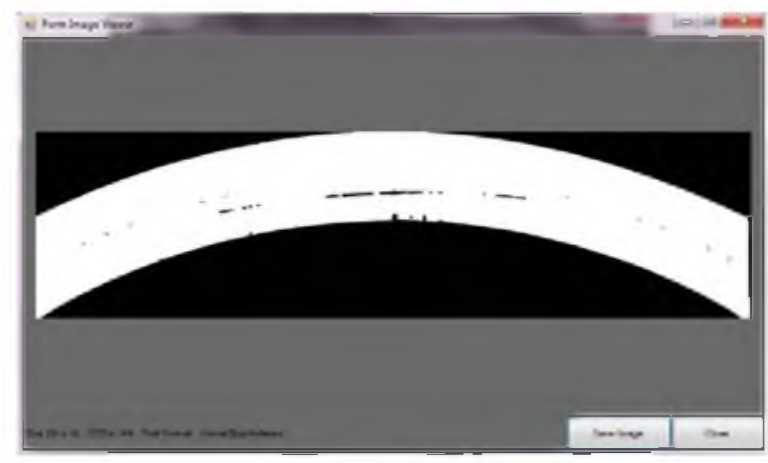

Gambar 5. 5. Implementasi Output Opening

Gambar 5.5 merupakan hasil dari uji fungsi opening. Pada pengujian ini fungsi opening berhasil meminimalkan noise yang mengganggu perhitungan objek bekas bakar.

f) Uji Fungsi Segmentasi dengan Noise Removing

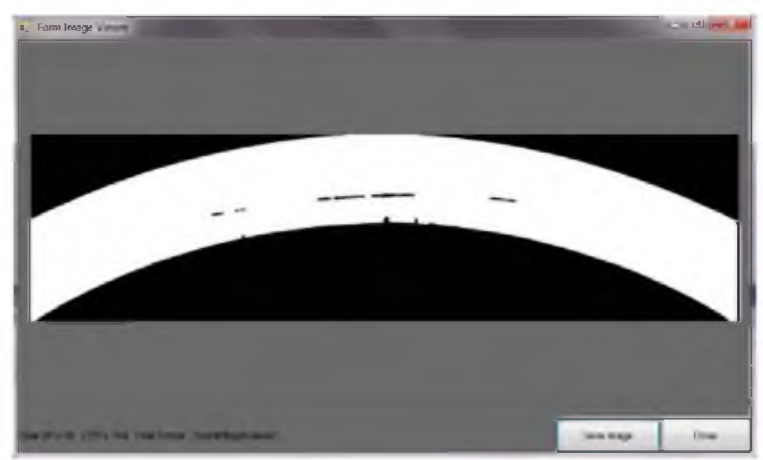

Gambar 5. 6. Implementasi Output Noise Removing

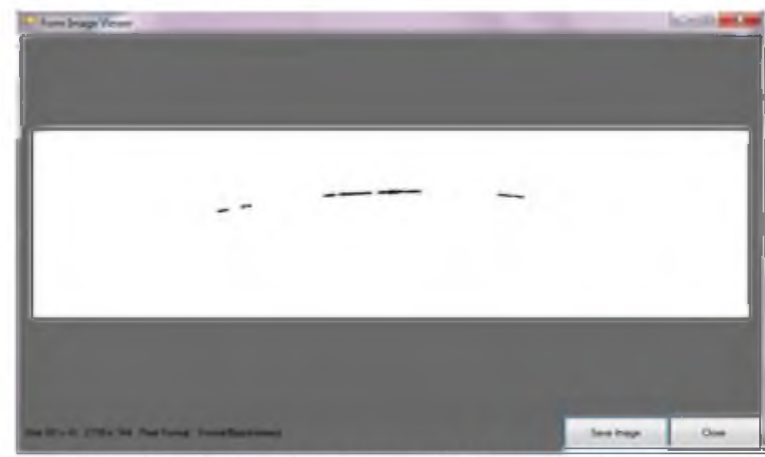

Gambar 5. 7. Implementasi Output Segmentasi

Pada uji fungsi noise removing dilakukan dengan menentukan jumlah pixel untuk menghilangkan noise disekitar objek dan noise yang melekat dengan tepi citra. Hasil pengujian dapat dilihat pada gambar 5.6 dan 5.7 Hasil perhitungan objek hasil segmentasi dapat dilihat pada gambar 5.8. 
g) Uji Fungsi Hasil Perhitungan Jumlah Objek

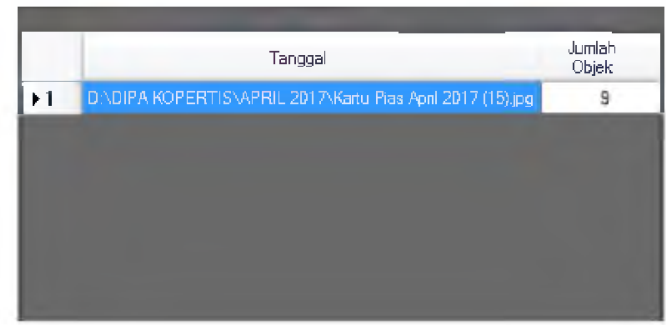

Gambar 5. 8. Implementasi Hasil Perhitungan Objek

\subsection{Uji Sistem}

Pengujian sistem bertujuan untuk memperoleh nilai (value) opening dan noise removing dengan tepat sehingga system akanmelakukan segmentasi dan memberikan output yang maksimal. Berdasarkan hasil pengujian sistem yang dilakukan, diperoleh nilai terbaik untuk segmentasi yaitu dengan opening radius 3 dan noise removing 125 pixel seperti terlihat pada tabel 5.1. dan gambar 3.7. Setelah diperoleh hasil uji fungsi dan system kemudian dilakukan pengujian terhadap 139 data yang menghasilkan RMSE 2.6485.

Tabel 5.1.Hasil Pengaturan Value

\begin{tabular}{|c|l|c|l|}
\hline N0 & \multicolumn{1}{|c|}{ Pengaturan Value } & $\begin{array}{c}\text { Jumlah } \\
\text { Objek yang } \\
\text { diperoleh }\end{array}$ & \multicolumn{1}{c|}{$\begin{array}{c}\text { Keterangan } \\
\text { Pengujian }\end{array}$} \\
\hline 1 & $\begin{array}{l}\text { Opening Radius 1, Noise } \\
\text { Removing 50 pixel }\end{array}$ & 49 & $\begin{array}{l}\text { Hasil segmentasi, noise masih terlihat } \\
\text { jelas berbentuk garis skala kartu pias. }\end{array}$ \\
\hline 2 & $\begin{array}{l}\text { Opening Radius 1, Noise } \\
\text { Removing 100 pixel }\end{array}$ & 31 & $\begin{array}{l}\text { Hasil segmentasi, noise masih terlihat } \\
\text { jelas berbentuk garis skala kartu pias. }\end{array}$ \\
\hline 3 & $\begin{array}{l}\text { Opening Radius 1, Noise } \\
\text { Removing 125 pixel }\end{array}$ & 31 & $\begin{array}{l}\text { Hasil segmentasi, noise masih terlihat } \\
\text { jelas berbentuk garis skala kartu pias. }\end{array}$ \\
\hline 4 & $\begin{array}{l}\text { Opening Radius 1, Noise } \\
\text { Removing 150 pixel }\end{array}$ & 26 & $\begin{array}{l}\text { Hasil segmentasi, noise masih terlihat } \\
\text { jelas berbentuk garis skala kartu pias. }\end{array}$ \\
\hline 5 & $\begin{array}{l}\text { Opening Radius 2, Noise } \\
\text { Removing 50 pixel }\end{array}$ & $\begin{array}{l}\text { Hasil segmentasi, noise masih terlihat } \\
\text { jelas berbentuk titik-titik kecil skala } \\
\text { kartu pias. }\end{array}$ \\
\hline
\end{tabular}




\begin{tabular}{|c|c|c|c|}
\hline 6 & $\begin{array}{l}\text { Opening Radius } 2, \text { Noise } \\
\text { Removing } 100 \text { pixel }\end{array}$ & 21 & $\begin{array}{l}\text { Hasil segmentasi, noise masih terlihat } \\
\text { jelas berbentuk titik-titik kecil skala } \\
\text { kartu pias. }\end{array}$ \\
\hline 7 & $\begin{array}{l}\text { Opening Radius } 2, \text { Noise } \\
\text { Removing } 125 \text { pixel }\end{array}$ & 12 & $\begin{array}{l}\text { Hasil segmentasi, noise masih terlihat } \\
\text { jelas berbentuk titik-titik kecil skala } \\
\text { kartu pias. }\end{array}$ \\
\hline 8 & $\begin{array}{l}\text { Opening Radius } 2, \text { Noise } \\
\text { Removing } 150 \text { pixel }\end{array}$ & 10 & $\begin{array}{l}\text { Hasil segmentasi, noise masih terlihat } \\
\text { jelas berbentuk titik-titik kecil skala } \\
\text { kartu pias. }\end{array}$ \\
\hline 9 & $\begin{array}{l}\text { Opening Radius } 3 \text {, Noise } \\
\text { Removing } 50 \text { pixel }\end{array}$ & 25 & $\begin{array}{l}\text { Hasil segmentasi, noise masih terlihat } \\
\text { terdapat titik-titik kecil noise, diluar } \\
\text { objek target }\end{array}$ \\
\hline 10 & $\begin{array}{l}\text { Opening Radius } 3, \text { Noise } \\
\text { Removing } 100 \text { pixel }\end{array}$ & 10 & $\begin{array}{l}\text { Hasil segmentasi, noise masih terlihat } \\
\text { terdapat titik-titik kecil noise, diluar } \\
\text { objek target }\end{array}$ \\
\hline 11 & $\begin{array}{l}\text { Opening Radius } 3, \text { Noise } \\
\text { Removing } 125 \text { pixel }\end{array}$ & 9 & $\begin{array}{l}\text { Hasil segmentasi, bebas noise dan } \\
\text { menyisakan objek target. }\end{array}$ \\
\hline 12 & $\begin{array}{l}\text { Opening Radius } 3, \text { Noise } \\
\text { Removing } 150 \text { pixel }\end{array}$ & 7 & $\begin{array}{l}\text { Hasil segmentasi, bebas noise, } \\
\text { menghilangkan objek target kecil yang } \\
\text { dianggap target. }\end{array}$ \\
\hline 13 & $\begin{array}{l}\text { Opening Radius } 4, \text { Noise } \\
\text { Removing } 50 \text { pixel }\end{array}$ & 8 & $\begin{array}{l}\text { Hasil segmentasi, bebas noise, } \\
\text { menghilangkan objek target kecil yang } \\
\text { dianggap target. }\end{array}$ \\
\hline
\end{tabular}

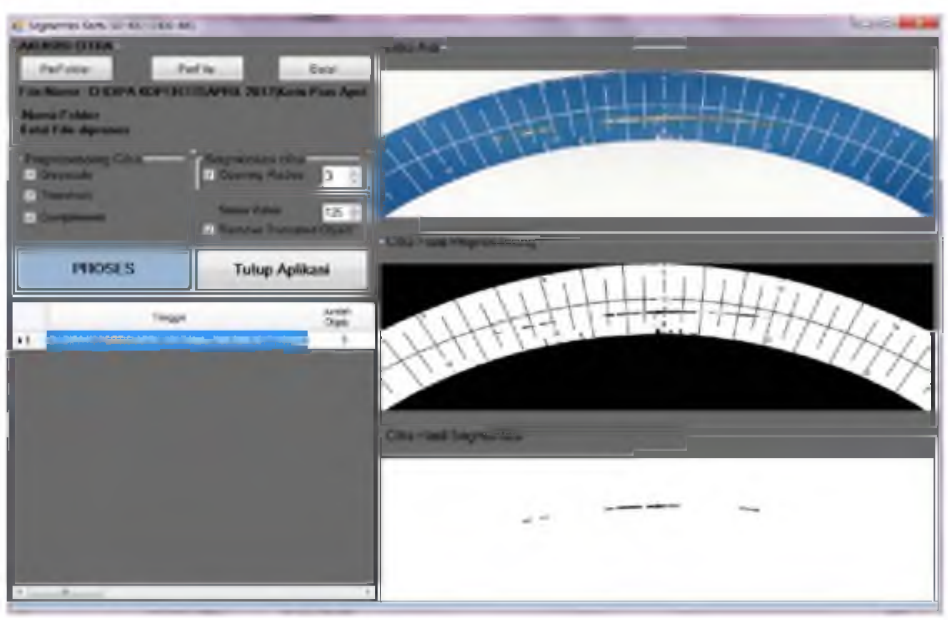

Gambar 5. 9. Uji fungsi system 


\subsection{Analisa Hasil Pengujian}

Berdasarkan analisa hasil pengujian sistem yang dilakukan, didapatkan RMSE 2.6485. Perbedaan perhitungan jumlah objek antara hasil hitung aplikasi dengan perhitungan manual operator antara lain beberapa factor :

1. Adanya objek hilang yang dikarenakan bentuknya terlalu kecil saat dilakukan noise removing, salah satu contoh adalah pengujian data tanggal 2 Juli 2017 dapat dilihat pada gambar 5.10.

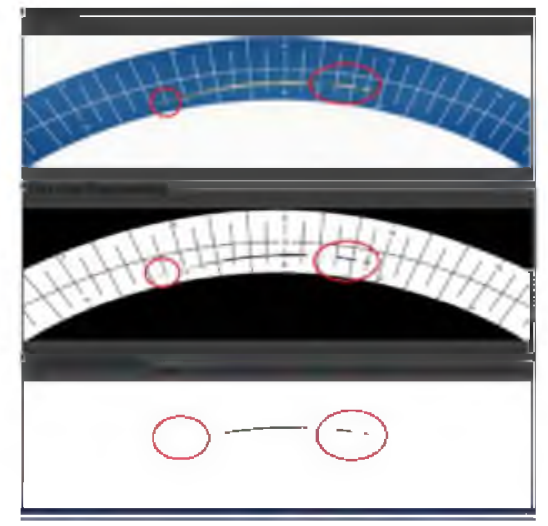

Gambar 5. 10. Objek kecil yang hilang

2. Objek memanjang dan tipis menyebabkan terbentuknya objek-objek saat dilakukan opening, salah satu contoh adalah pengujian data tanggal 16 Juli 2017 dapat dilihat pada gambar 5.11

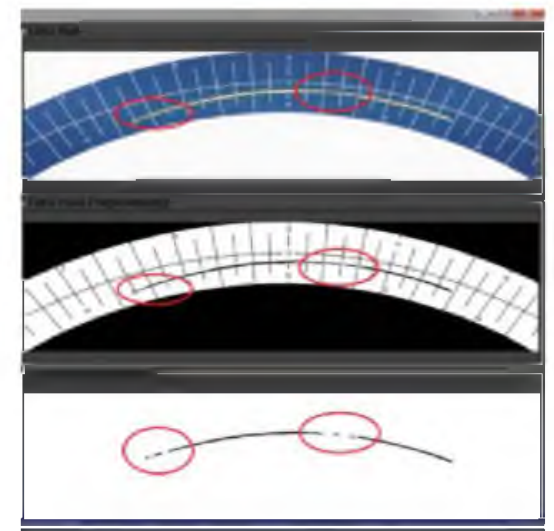

Gambar 5. 11. Muncul Objek baru

3. Terdapat kerusakan kartu pias yang menyebabkan terbentuknya objek yang bukan bekas bakar, tetapi saat segmentasi terlihat sebagai objek bekas bakar.

\section{Kesimpulan dan Saran}

\subsection{Kesimpulan}

Merujuk pada latar belakang permasalahan, tujuan penelitian dan hasil pengujian, maka dapat disimpulkan bahwa:

1. Penentuan nilai opening dan noise removing yang tepat akan menentukan hasil segmentasi. 
2. Segmentasi yang dihasilkan pada penelitian ini cukup baik dengan menghasilkan RMSE jumlah objek hasil segmentasi sebesar 2.6485 terhadap jumlah objek pada citra asli.

3. Selisih hasil perhitungan objek disebabkan oleh kesalahan segmentasi yang disebabkan oleh objek bekas bakar kartu pias yang kecil dan atau objek tembus namun tipis, sehingga objek sebagian hilang atau membentuk area pemisah objek.

\subsection{Saran}

1. Penelitian selanjutnya diharapkan dapat menentukan metode segmentasi yang tepat sehingga hasilnya lebih akurat.

2. Disarankan untuk penelitian selanjutnya, citra uji lebih difokuskan pada area target dengan menghilangkan bagian citra saat preprosessing.

\section{Ucapan Terimakasih dan Penutup}

Peneliti mengucapkan terima kasih yang sebesar-besarnya kepada Kopertis V DIY atas pendanaan pada penelitian ini, yang disalurkan melalui program hibah DIPA KOPERTIS V DIY Tahun Anggaran 2017 No. 02/K.2.2/Dik-P3M/VI/2017.

Besar harapan peneliti bahwa dengan adanya penelitian lanjutan, maka rancang bangun aplikasi terus berkembang dan dapat meningkat kualitas outputnya. Sehingga dapat dimanfaatkan secara nyata untuk membantu pekerjaan operator stasiun klimatologi dan informasi yang dihasilkan teruji valid. Peneliti menyadari bahwa penelitian yang dilakukan ini masih jauh dari sempurna. Untuk perbaikan ke depan maka peneliti menerima saran maupun kritik yang bersifat membangun.

\section{Daftar Pustaka}

Ariffin., Bahri, S., Sulistiono, R., Haryono, D., Suminarti, N., dan Herlina, N., 2010, Modul Praktikum Klimatologi. Fakultas Pertanian Universitas Brawijaya, Malang

BMKG, 2006, Peraturan Kepala Badan Meteorologi dan Geofisika no SK/32./TL.202/KB/BMG-2006

Fan, Q., dan Zhang, Y., 2013, A scorch extraction method for the Campbell-Stokes sunshine recorder based on multivariable thresholding. Imaging Systems and Techniques (IST), IEEE International Conference on, $410-414$.

Gonzalez, R.C. dan Woods, R.E., 2008, Digital Image processing, Addison- Wesley Publishing Company, USA

Hamdi, S., 2014, Mengenal Lama Penyinaran Matahari Sebagai Salah Satu Parameter Klimatologi. Berita Dirgantara, 15(1), 7-16

Horseman, a. M., Richardson, T., Boardman, a. T., Tych, W., Timmis, R., dan MacKenzie, a. R., 2013, Calibrated digital images of Campbell-Stokes recorder card archives for direct solar irradiance studies. Atmospheric Measurement Techniques, 6(5), 1371-1379 
Kuivalainen, M., 2005, Retinal Image Analysis Using Machine Vision, Tesis, Depatement of Information Technology, Lappeenranta University of Technology, Lappeenranta

Lakitan, B., 1994, Dasar-dasar Klimatologi. Jakarta: PT. Rajagrafindo Persada.

Muhsoni.F.,F. Effendy M,danTriajie, H.2009. Pemetaan Lokasi Fishing Ground dan Status Pemanfaatan Perikanan di Perairan Selat Madura.Ilmu Kelautan Universitas Trunojoyo Madura

Pujiastuti, A., Harjoko, A. 2016. Sistem Perhitungan Lama Penyinaran Matahari dengan Metode Otsu Threshold (Study Kasus: St. Klimatologi Barongan),Tesis, Program Studi S2 Ilmu Komputer Fakultas Matematika dan Ilmu Pengetahuan Alam Universitas Gadjah Mada Yogyakarta

Qingming, H., Wen, G., Wenjian, C. (2005), Thresholding Technique with Adaptive Window Selection for Uneven Lighting Image, Pattern Recognation, vol. 26, hal.801-808

Sanchez-Romero, a., González, J. a., Calbó, J., dan Sanchez-Lorenzo, a., 2014, Using digital image processing to characterize the Campbell-Stokes sunshine recorder and to derive high-temporal resolution direct solar irradiance. Atmospheric Measurement Techniques Discussions, 7(9), 9537-9571

Strangeways, I. A. N., 2003, Measuring The Natural Environment (2nd ed., p. 548). Cambridge University 
